\title{
TEACHING WRITING RECOUNT TEXT AT EIGHT GRADE USING THINK-TALK-WRITE TECHNIQUE BY DIGITAL STORYTELLING
}

\author{
Muhammad Faozi Baidhowi ${ }^{1}$, Mundriyah Pamungkas² \\ ${ }^{1}$ IKIP Siliwangi \\ ${ }^{2}$ IKIP Siliwangi \\ ${ }^{1}$ Ozibaidhowi@ student.ikipsiliwangi.ac.id, ${ }^{2}$ Mundriypamungkas@ikipsiliwangi.co.id
}

\begin{abstract}
Based on the fact that the students writing ability, was very low, so the students had difficulties in writing especially writing recount text. The aims of this research to find out: 1) The implementation of the scenario in teaching English writing recount text using think-talk-write technique by digital storytelling 2) The students difficulties in learning writing recount text using think-talk-write technique by digital storytelling. This study used descriptive qualitative research. The subject of the study was the eight grade students in one of junior high school that consist of twenty students. The instrument used in this study were observation sheet and questionnaire. The results of this study indicated that the implementation of teaching and learning process was done in accordance with the scenario that had been made by the researcher. The initial assignment was given to the students to know what are the difficulties faced by the students. Based on the result, it could be mentioned that the students difficulties were the use of grammar, poor vocabulary-especially in spelling and how to use appropriate vocabulary. After learning using the TTW technique, the students could overcome their difficulties. They could understand better the use of grammar and structure, appropriate vocabulary and better in spelling.
\end{abstract}

Keywords: Think-Talk-Write, Digital Storytelling, Writing

\section{INTRODUCTION}

It cannot be denied anymore that English is an important international language to be used and applied in the world of work and education. In Indonesia, English is learned by students beginning from kindergarten, elementary school, junior high school, senior high school and even universities. There are four skills in English namely listening, speaking, reading, writing with sould be able to understand by learners. Writing is one of this for skill with sould be learned and applied correctly by students at eight grade of junior high school. According to Yanuarti Apsari (2018) in Kareviati Evie,Yugafiati Rasi\&Resmini Setya (2020) people who learn to write English certainly have goals for their work or academics. In line with this, Graham (2006) as cited in Parmawati, Santoso, Yana (2020) states that students have to struggle significantly with writing and if someone does not write well he will find difficulties in the process of learning, education, andwork. So, it can be concluded that writing is a complex process which is neither easy nor spontaneous for many second language learners.

For example, students majoring in English are learning to write English because they have a goal to completed that is for their final academic assignment. While Lanchard and Root (1998: 1) as cited inWidayanti, Rustyana, \& Haryudin, (2019) are guide that learning the ability to write in a foreign language is difficult. It is supported by Rizqiya (2017) Siska Rizkiani, Gartika Pandu \&Bhuana, (2020) before writing someone needs to find out about what will be written, 
knowledge of grammar, syntax, mechanics, organization of ideas which will later be included in the part of writing.

In teaching writing it is necessary to choose a suitable approach, method, technique, and also media to make students understand what they are learning. One of the techniques in teaching writing introduced by Huinker and Laughlin (1996: 82) inDina Lisnawati, Diana Elvirasari,\&Iman Santoso (2019) is think-talk-write technique. This technique in courageous the students to be able to think affectively, to speak and to express their idea freely and to write their idea with ease. This technique is usually done in groups of 3-5 students.

It is explain further that the first step of TTW technique is required for each student to think about the material being explained, to make important notes about the material. Then the second step, the students make a talk with the groupmate to discuss the results of the note that they take in the first step. By making the notes the students will obtain the purpose and essence of the material in discussion. The third step, the students poured the results of the discussion into a written form. With this TTW technique, the students are expected to be active in teaching learning process they can improve both their speaking and writing ability.

Practicing think-talk-write technique in learning to write needs to be held by using a media in order to assist in the application of this technique. The media in learning to write are supposed to support students to be involved in teaching learning process. One of the media which can be used is digital storytelling. According to Lambert (2012) cited in Bloch (2018)digital storytelling is a story in the form of a digital narrative that consists of visual, oral and aural elements to tell an event, one's experience and others. Therefore, when using digital media storytelling, students will be more enthusiastic because the media are more modern and sophisticated.

In learning writing recount text students should understand the generic structure of the text. According to Gerot and Wignell (1994) inShopiah \& Anggraeni (2018) recount text is a text that aims to entertain readers about experience. Recount text has a generic structure, according to Utami (2012) inRadhita Vidya, Annisa Nuraini\&Odo Fadloeli (2019) Generic structure in recount text consists of orientation, introduction at the beginning of the text, events, tells about events, and re-orientation - conclusions from the story.

\section{METHOD}

This study used descriptive qualitative methods. The researcher used observation sheets, questionnaires, document to collect the data. According to Sandelowski, as cited inNurmalasari \& Apsari (2019) qualitative descriptive research can be said as a categorical, as inversely proportional to a non-categorical, alternative for inquiry.

Observation sheet was given to the teacher as an observer is to see the scenario which was prepared by the researcher whether implemented in teaching writing recount text in the class. Questionnaire and Document were used to know the students difficulties in learning writing recount text. The questionnaire were given to the students. The questionnaire were consisted of yes and no question and open ended question. Whereas the document was taken from the result of the students assisments before and after the teaching lerning process.

The subject of the research was grade eight in one of junior high school the total of the students are twenty, which consisted of male and female students. 
The followings are the instrument with were used to obtain the data.

Table 1.

Observation sheet for teacher

\begin{tabular}{l}
\hline No \\
\hline \hline 1. Researchers opened the class by examining and examining the attendance of \\
students \\
\hline 2. The researchers introduces the topic to students \\
3. Researchers pay close attention to and examine them seriously \\
4. The researchers identifies the understanding of peace of mind about the recount \\
5. The researchers introduces the text model of student recount text \\
6. The research describes the energy and energy structural features of student \\
7. The research involved a lot of students about text reports \\
8. Students answered questions from researchers \\
9. Research provides examples of recount \\
$\mathbf{1 0}$ Students provide examples of text recounts \\
$\mathbf{1 1}$ Students gave a good response to the researchers \\
$\mathbf{1 2}$ Students make notes to write important information \\
$\mathbf{1 3}$ Students attend the study seriously \\
$\mathbf{1 4}$ Researchers Apply Think-talk-write Techniques in teaching and learning \\
$\mathbf{1 5}$ The researchers divides into several groups - couples \\
$\mathbf{1 6}$ The students discussed with their friends \\
$\mathbf{1 7}$ Researchers provide time for students to work together - create groups and \\
$\mathbf{1 9}$ The research gives time to students to submit their questions related to the recalls \\
\hline
\end{tabular}

Note : I = First observation teacher

$\mathrm{II}=$ Second observation teacher

Table 2.

Questionnaire for students

Questionnaires were given to students after all material was completed during three meetings. The questionnaire has four main indicators namely attention, relevance, convidence, and satisfaction.

Source: adapted fromMuhlisin (2018) 


\begin{tabular}{|c|c|c|c|}
\hline No & Statement & Yes & No \\
\hline 1 & $\begin{array}{l}\text { Does learning to write with think-talk-write techniques that } \\
\text { have been applied make you have a high willingness to follow } \\
\text { the lessons? }\end{array}$ & & \\
\hline 2 & $\begin{array}{l}\text { Whether learning to write with think-talk-write techniques } \\
\text { that have been applied can reduce errors in learning to write? }\end{array}$ & & \\
\hline 3 & $\begin{array}{l}\text { Does the learning that has been done make it easier for you to } \\
\text { understand the learning material? }\end{array}$ & & \\
\hline 4 & $\begin{array}{l}\text { Whether learning to write with the applied think-talk-write } \\
\text { technique makes it easy for you to understand the material } \\
\text { being taught? }\end{array}$ & & \\
\hline 5 & $\begin{array}{l}\text { Whether learning to write with think-talk-write techniques } \\
\text { that have been applied is more interesting, fun and not boring? }\end{array}$ & & \\
\hline 6 & $\begin{array}{l}\text { Do you feel the time given by the teacher to understand the } \\
\text { material goes quickly? }\end{array}$ & & \\
\hline 7 & $\begin{array}{l}\text { By using think-talk-write techniques that have been applied, } \\
\text { do you become motivated to get better grades? }\end{array}$ & & \\
\hline 8 & $\begin{array}{l}\text { Whether learning to write with the think-talk-write technique } \\
\text { that has been applied can improve your critical thinking skills } \\
\text { individually? }\end{array}$ & & \\
\hline 9 & $\begin{array}{l}\text { Do you feel more valued when expressing opinions while } \\
\text { studying in class? }\end{array}$ & & \\
\hline 10 & $\begin{array}{l}\text { Do you become more courageous in expressing opinions in } \\
\text { the learning process in class? }\end{array}$ & & \\
\hline
\end{tabular}

\section{Open Ended}

1. What are your difficulties in this learning process? Do you feel happy when you are learning English using this technique think talk write? Explain!

2. Among learning to write in English what is the most difficult to learn?
a) Organization/ paragraphing
b) Logical development of idea/content
c) Grammar/ syntax
d) Punctuation, spelling and mechanics
e) Vocabulary

(Sort according to the level of difficulty in your opinion).

\section{RESULTS AND DISCUSSION}

\section{Results}

In this section should the result of the research. Observation analysis results from the teacher and student response questionnaire, the results of which will be displayed in a table.

Table 3.

Observation sheet for teacher
No
Statement 
1 Researchers open the class by examining the attendance of students

2 The researchers introduces the topic to students

3 Researchers pay close attention to and examine them seriously

4 The researchers identifies the understanding of peace of mind about the recount

5 The researchers introduces the text model of student recount text

6 The researchers described the energy and energy structural features of student recounts

7 The researchers involved a lot of students about text reports

8 Students answered questions from researchers

9 Researchers provides examples of recount

10 Students provide examples of text recounts

11 Students gave a good response to the researchers

12 Students make notes to write important information

13 Students attend the study seriously

14 Researchers Apply Think-talk-write Techniques in teaching and learning

15 The researchers divides into several groups - couples

16 The students discussed with their friends

17 Researchers provide time for students to work together - create groups and discuss

18 Research provides assignments

19 The research gives time to students to submit their questions related to the recalls

$\begin{array}{llllll}\mathbf{I} & \mathbf{I I} & \mathbf{I} & \mathbf{I I} & \mathbf{I} & \mathbf{I I} \\ \sqrt{ } & \sqrt{ } & \sqrt{ } & \sqrt{ } & \sqrt{ } & \sqrt{ }\end{array}$




$\sqrt{ } \sqrt{ } \sqrt{ } \sqrt{ } \sqrt{ } \sqrt{ }$

\section{Note $: \mathrm{I}=$ First observer \\ $\mathrm{II}=$ Second observer}

Based on the steps in the lesson plan

From the results above, it can be concluded that, at the first meeting, the first observer had seen that the research teacher saw some students were less serious in learning. While the second observer had seen that the researcher did not identify the main understanding of students in dealing with the recount text. At the second meeting, the first observer had given the point that all twenty statements in the observation sheet for teacher had been applied accordingly by the research. Whereas the second observer had seen the researcher paid attention to the material but did not examine them seriously and some students were less serious in following the lessons. At the third meeting, the first and second observershad seen that the researchers had carried out all the statements during the teaching learning process.

From the first to the end that the research teacher had opened the class by greeting and checking the attendance list of students, the research teacher had introduced the topic to students, the research teacher had paid attention to recount text material and examine student results seriously, the research teacher has identified the student's main understanding of the recount text, the research teacher has introduced the recount text model to students accordingly, the researcher has explained the generic structure and language features of the recount text to students, researchers have asked the students about recount texts, observer teachers have seen students answer questions from researchers, researchers have given examples of recount texts, students have given examples of recount texts, students have given good responses to researchers, students have made notes to write informational information ting, students have taken lessons seriously, researchers have applied think-talk-write techniques in the teaching and learning process, researchers have divided students into groups, students have discussed with their peers, researchers have provided time for students to work together ie creating groups and discuss, researchers have given assignments, researchers have given time to students to submit their questions related to the recount text, researchers have closed the meeting with greetings.

The following is the results was taken from the students' questionnaire.

Table 4.

Results of students' questionnaire

\begin{tabular}{ccccc}
\hline Indicator & Question & Yes & No & Total \\
\hline Attention & 1 & $100 \%$ & $0 \%$ & $100 \%$ \\
& 2 & $70 \%$ & $30 \%$ & $100 \%$ \\
& 3 & $95 \%$ & $5 \%$ & $100 \%$ \\
Relevance & 5 & $85 \%$ & $15 \%$ & $100 \%$ \\
& 6 & $95 \%$ & $5 \%$ & $100 \%$ \\
& 6 & $80 \%$ & $20 \%$ & $100 \%$ \\
\hline
\end{tabular}




\begin{tabular}{lcccc}
\hline Confidence & 7 & $95 \%$ & $5 \%$ & $100 \%$ \\
& 8 & $95 \%$ & $5 \%$ & $100 \%$ \\
Satisfaction & 9 & $90 \%$ & $10 \%$ & $100 \%$ \\
& 10 & $95 \%$ & $5 \%$ & $100 \%$
\end{tabular}

From the table above it can be described about the result of questionnaire given to the students during the teaching-learning process. In the first indicator (attention) all the students agree with the statement that learning to write with the TTW technique that has been applied makes students have a high willingness to attend the lessons. Almost all students agree with the statement that learning to write using the TTW technique could reduce errors in learning to write. A few of students did not agree with the statement that learning using TTW made easier for students to understand the learning material. Very few students who disagree with the statement that learning using TTW make to write using the written-thought-speak technique makes it easy for students to understand the material being taught. Indicator in the relevance column only a few of students who did not agree with the statement that learning to write with TTW technique is more interesting, fun and not boring. Very few students who did not agree with the statement that students felt the time given by the teacher to understand the material when quickly. Indicator of confidence only a few of students who did not approve the statement that by using the TTW technique motivated to get better grades and improved the students' criticall skills individually. In the satisfaction column, almost all students agree with the statement that students felt more valued when expressing opinions while studying in class and becamed more courageous in expressing their opinions in the learning process in class.

The results of the analysis of the questionnaire to determine student difficulties will be displayed in the table below.

\section{Table 5}

Factors of students' difficulties

\begin{tabular}{clc}
\hline No & \multicolumn{1}{c}{ Factors } & Percentages \\
\hline $\mathbf{1}$ & $\begin{array}{l}\text { Difficult to memorize, remember, translate, } \\
\text { and not much to know about vocabulary. }\end{array}$ & $35 \%$ \\
$\mathbf{2}$ & $\begin{array}{l}\text { When creating stories like recount text, } \\
\text { they had difficulty because they translated } \\
\text { from Indonesian into the English language } \\
\text { not translating directly. }\end{array}$ & $20 \%$ \\
$\mathbf{3}$ & $\begin{array}{l}\text { Grammar, that they still have difficulty } \\
\text { using verbs in the past tense form. } \\
\mathbf{4}\end{array}$ & $\begin{array}{l}\text { They don't understand the use of a } \\
\text { punctuation point in writing english }\end{array}$ \\
\hline
\end{tabular}

On table five it shows the analysis of students answers about students' difficulties in learning English. It can be concluded that there are four factors that influence why writing is a difficult subject for them. First, from twenty students, $35 \%$ of them were having Difficulties to memorize, remember, translate, and did not no much about vocabulary.

Because the students' vocabulary was limited, when students would make a story they only to used some of the vocabulary when they wrote the story. The second factor, $20 \%$ of students said that when they wrote stories in recount text, because they translated the words from Indonesian into English. They had difficulties to write dirrectly in English. The third factor is 


\section{Volume 3, No. 6, November 2020 pp 670-679

Grammar, that they still a difficulty using verbs in the past tense form, $40 \%$ of the students stated that they had difficulty using grammar when making recount text stories. The fourth factor, $5 \%$ of the students stated that they didn't understand the command point in writing.

The analysis of document is the analysis of documents from the results of student assessments given before and after the teaching-learning process. Previously, students still found it difficult to use the appropriate vocabulary, use the right form of the verb in the past tense. In writing recount text they still didn't understand the use of appropriate generic structure and they didn't understand the use of punctuation in writing English. After having studied for three meetings. They increased there understanding how to use the generic structure.

\section{Discussion}

From the observation table analysis for student teacher activities during three meetings, it can be discussed that the implementation of teaching English with think-talk-write techniques by the research teachers was going on well. This can be seen from the observation table for the teacher, at the first meeting the research teacher had taken steps in applying the think-talk-write technique, the teacher's first observer shows students attending learned seriously but is overcome by teacher research by giving more focus to students who are not serious about studying. The second observer teacher noticed that the research teacher had not yet identified the students understanding about recount text. At the second meeting, the first observer teacher sees the research teacher has taken all the steps in applying the thinking-speak-writing technique perfectly. The second observer teacher noticed that the research teacher paid less attention and checked the results of students' text calculations because it turned out that the research teacher only examined a number of results that were used as samples to shorten the time. in teaching. In this second meeting the observer teacher also saw that some students were less serious in participating in learning. At the third meeting of the first and second observers, the teacher saw that all the steps involved in applying the thinking-speak-writing technique in learning English recount texts had been going well and perfectly so that nothing was missed.

The researcher has made a scenario based on the recount text material that would be used in research learning. This think-talk-write technique had been implemented in grade 8 in junior high school. Researchers have used this technique because this technique made it easy for students to learn to write. Before researchers studied the material, researchers had given orders the students had to form groups of 4-5 students. After that the researcher gave a video on the theme of recount text to students. Then students think to understand and record the essence of the video shown through digital storytelling media, this stage is called thinking. The next stage is talk. After students got an understanding of the contents and essence of the video that had been shown and they had written some notes about their own discussion of the video, students they work asked to discuss with classmates, exchanged ideas, found the right ideas about the video. The last stage that had to be done was the task full of students to rewrite the text using their own language according to the theme that had been displayed through digital media storytelling using generic structure recount text that had been explained at a meeting in class.

From the first assisgment given by the researcher, it had been found that the students difficulties were using appropriate vocabulary due to there limitation in vocabulary. They also made mistakes in word spelling, when writing stories in recount text. This happened because must of them translated the text from Indonesian into English. In addition, they still did not understand the form of the regular and irregular verbs in the past tense form. They didn't understand to 
used appropriate punctuation in English. After giving the first assisnment the research teacher conducted a study for three meetings using think-talk-write techniques with digital storytelling media and held a final assisnment. The results of this assisnment should that the students could understand better in writing recount text. Eventough there were still a few students who could not master there a writing ability. In the initial assignment many students have difficulty spelling and finding the correct vocabulary with the final assignment held all students can spell and find the correct vocabulary with the help of a dictionary. At the end of the assignment, almost all students have been able to make a recount text story by translating from Indonesian into English properly without experiencing difficulties as in the initial assignment. Some students are still a little confused in the use of past tense verbs. In the final assignment students have understood the use of command points in making story recount texts.

To compare with the open-ended questions where given to the students it was found similar results they stated that some difficulties on the use of past tense regular and irregular because they could not memorize the verb easyly. They had difficulties to translate directly in English. They formarly did not familiar with the use of the generic structure of the recount text. However, after the teaching learning process the said that they understood better how to write the recount text. It can be also explain that there were a lot of change in students attitude, attention, behaviour and confidence after the teaching learning process. All this changegis effected the results that they achieve at the end after meeting.

That there are changes in learning both student attitudes, attention, behaviour so that the changes affect the results so that they can follow lessons better, the results are better, can reduce their difficulties. Based on the results of this research related to the findings of the study with was done by Uswatun Hasanah (2019) it could be concluded that the think-talk-write technique could improves the students' ability in writing text.

\section{CONCLUSION}

From the previous explanation it can be concluded that of this research related to the findings of the study with was done. The scenario had been implemented well by the researchers during the teaching learning process. The study could overcome the students difficulties in the use of appropriate vocabulary, improve in the words spelling, and make students understand how to use the verbs in the past tense form.

\section{ACKNOWLEDGMENTS}

First of all, thanks to Allah SWT for his grace and guidance in giving the researchers full strength to complete this article. Eventough facing some difficulties in completing this article, finally the researchers could a compplish it. Thanks very much to all the persons who had given their support and guidance in compliting this article. Then, thanks a lot to both of the parents who had pationly supported during the study.

\section{REFERENCES}

Bloch, J. (2018). Digitalstorytellinginthemultilingualacademicwriting classroom: expandingthepossibilities. Dialogues Aninterdisciplinary Journal of English Teaching and Reseacrh, 2(1), 96-110.

Dina Lisnawati, Diana Elvirasari, \& I. S. (2019). Improvingstudents' writingabilitythroughthinktalk writemethod. PROJECT (Professional Journal of English 
Education), 2(3), 306-309.

Hasanah, U. (2019). Using Think Talk Write ( TTW ) strategy to improve students' writing skill in descriptive text at the eleventh grade of SMA Negeri 4 English education study programfacultyof tarbiyahand teacherstrainingstateislamicinstituteofpalopousingthink TA. English Education Study Program Faculty of TARBIYAH and Teachers Training State Islamic Institute of Palopo.

Kareviati Evie,Yugafiati Rasi, R. S. (2020). Need analysis of English department students as the basic of material development of. ELTIN JOURNAL, Journal of English Language Teaching in Indonesia, 8(1), 8.

Muhlisin, A. (2018). Analysis of students'response of the implementation of rms (reading, mind mapping, and sharing) learning model in philosophy of science. Unnes Science Education Journal, 7(1), 13-18.

Parmawati, A., Santoso, I., \& Yana, Y. (2020). Improving Students'writing Skill Through Round Table Technique. ELTIN JOURNAL, Journal of English Language Teaching in Indonesia, 8(2), 103-111.

Nurmalasari, M., \& Apsari, Y. (2019). Improving students' participation in speaking. 2(2), 1420.

Radhita Vidya, Annisa Nuraini, \& O. F. (2019). Improvingstudents' readingcomprehensionofrecount text by using Think-Pair-Share (TPS)technique. PROJECT (Professional Journal of English Education), 2(2), 146-155.

Shopiah, S., \& Anggraeni, R. (2018). Teaching recount text through scrabble game.01(03), 201-206.

Siska Rizkiani, Gartika Pandu \& Bhuana, R. S. R. (2020). Coded Vs Uncoded corrective feedback. ELTIN JOURNAL, Journal of English Language Teaching in Indonesia, 8(1), $55-66$.

Widayanti, T., Rustyana, N., \& Haryudin, A. (2019). Students' perception in writing. 2(5), 687691. 